\title{
船舶法第二十二条と国際法
}

\author{
佐 藤 好 明*
}

\section{The International Legal Problems of the Japanese Vessel Act Article 22, Clause II}

Yoshiaki SATO

\begin{abstract}
The use of national flags by ships is limited only to its nationals except when it is employed in time of war to escape capture by enemy vessels. It is expressly permited to foreigners by the British Shipping Act of 1894, Sec. 691 and the present Japanese Vessel Act, Article 22, Clause II. In spite of somewhat misleading interpretation by Japanese municipal lawyers to take caputure for arrest in time of peace, these stipulations have the same origin found to be traced back to the French Maritime Ordinance of 1650 which prescribed for French captains not to hoist other banners than France's while waging war. In the days of this ordinance French marines were too weak to engage war on the sea. Besides the exceptional and rare ships which the Admiral fitted out at his own expense, available were only privateers armed by private persons. Their greed for gains forced themselves to neglect sufficiency of armament during wars and exposed the flag of France to insult very often. Harsh pillage was committed even after truce to the detriment of the honour of the king of France and his allies. This state of affairs led to the above mentioned ordinance to bring order to naval wars. But approximately after 1681 ordinance of France it had been almost always permited for the privateers to keep aboard any flags which they judged as proper and to use them when driven by necessity in order either to recognise better the ship they encountered or to escape the pursuit by enemy which they assumed stronger than themselves. What was prohibited was to attack under false flags or colours and mainly concerned privateers, for they were the first to disguise their nationality as a ruse of war. War ships were, as it was expected, the last to hide their nationality to avoid battle with enemy war ship or to attract merchant ship apparantly fragile to resist.

It is so natural for this ruse of war to authorise victim of privateers to do the same thing. For a long time this custom could have been maintained without considerable trouble. So long as the speed of war ships was slow and their range was short, no fatal surprise could threaten. A suspicious ship could be observed long before it became dangerous. There was wide room for merchant ships to escape and enough time to make preparation for the combat. Even if a false flag enabled an enemy to approach and fire, the first attack could be rarely fatal.

Modern weapon can fataly attack targets beyond visual range or even over the horison where it is impossible to confirm that the target is a legitime military object. The maintenance of this ruse of flag greatly increase the danger to neutrals which Japan has much possibility to become in future armed conflicts. In 1915 the U.S.A. protested the British ship, the Lusitania, wearing American colours in the war area. Strongly worded protests were also presented to Britain from the Netherlands and the three Scandinavian states. Their common ground was that this
\end{abstract}

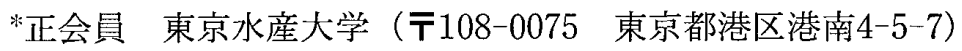


old rule had become obsolete. It is difficult to see why the law of the sea should continue to tolerate method of deception originating from privateers' discretion of oppotunistic choice between assaulting the weak and retreating from the strong. We need not go so far as dealing all aspects of ruses of war concerning ships. What can be and what should be done is to deplete the exemption clause of the Article 22 of the Japanese Vessel Act to keep free hand in our diplomacy.

\section{1. 序論 問題の所在}

船舶法第二条は日本船舶でなければ、日本の国旗を掲げることを禁止し、この禁止に違反すれば、同法 第二十二条第一項で船長を二年以下の懲役に処し或は十万円以下の罰金を課すと定めている。更に第二十 二条第二項は、「船舶が捕獲を避けんとする目的を以て日本の国旗を掲げたるときは之を適用せず」と断っ ている。

船舶法の解説によっては、船舶法第二十二条第二項の「捕獲」の意義を、平時の「拿捕」と混同させる恐れ のある表現を用いているものがある。

同じ船舶法第三条は日本船舶でなければ、不開港場に寄港する事等を禁じ、違反すれば、同法第二十三 条で、やはり、船長を二年以下の懲役に処し或は十万円以下の罰金を課すと定めている。この点にも第三 条但書があり、「捕獲を避けんとするとき…此限に在らず」と断っている。第二十二条第二項の「捕獲」と 第三条但書の「捕獲」とは全く同じ意義、即ち戦時捕獲の意義を持つと解される。しかし、「法務研究報告書」 第67集第 2 号、p.89、昭和55年、は、この「捕獲」の意義について横田喜三郎博士著「国際法 $I 」 137$ 頁以下を 参照して確認すべきとしている。昭和33年刊の初版本は、確かに138頁で平時の拿捕について「捕獲」の語を 用いて、公海における取締を扱っている。しかし、昭和47年の新版では捕獲を「拿捕arrest」の語に代えてい $ろ^{(1)}$ 。

もし船舶法第二十二条第二項の「捕獲」の意義を平時の拿捕と解釈すると、公海での違法行為を宥恕し、 或は、我が国の権限を自縄自縛しかるね水な奇妙な規定という事になってしまう。

先ず、我が国による平時の拿捕を免れる為に、非日本船が日本国旗を揭げを場合、罰則を適用出来ない 事になる。これでは日本国旗の乱用の嫌疑で船舶を取締る権限を、船舶法第二十二条第二項が自ら放棄す るか、少なくとも、その効果を減殺する事になり、船舶法第二条の立法目的を損なう。

次に公海で、非日本船舶が、我が国旗の下に、真の旗国の刑事管轄権の行使を受けるべき衝突や刑事事 件を引き起こした後に、我が国領海内に至ったと仮定する。この場合、日本国旗を掲げた事実によって真 の旗国の公海での刑事管轄権を免れ、更に日本領海内でも、真の紐帯が存在しない故を以て、我が国の管 轄権も免れる事は十分起こり得る。しかも、衝突や刑事事件などの問題を別にして、我が国の国旗の不正 使用も、真の旗国の刑事管轄権に基づく拿捕を免れる目的で行ったと当該船舶が主張すれば、船舶法第二 十二条第二項に関する上の解釈によって処罰されずにすむ事になる。これでは我が国が、公海上での違法 行為の他国による取締の効果を減殺し、我が国法違反を宥恕し、しかも我が刑事・行政管轄権を自縄自縛 する事になる。このとき第二十二条第二項の存在理由は極めて疑わしいものになる。

類似の規定を外国の例に求めると、1894年の英国商船法第69条第 1 項は、「英連邦船舶に見せかけ付目的 で、英連邦船舶を所有する資格の無い者の…所有する船舶で、英連邦国旗 (the British flag) を揭げ或は英 連邦国籍(the British national character)を偽装すれば、当該船舶を…没収するものとする。」定めてい るが、ここでも、但書があり、「偽装 (assumption)が、敵或は交戦権を行使する外国軍艦による捕獲 (capture)を免れる目的でなされた場合を除く。」と明記している(2)。従って1894年の英国商船法については、戦 時或は武力紛争時の捕獲についての例外規定である事に疑問の余地はない。尚、同様の規定がイタリアに も在ったとされる(3)。

我が国の先学も同じ解釈をして、英国の慣例に追従したものであると現船船法第二十二条第二項の前身 たる帝国船舶法第二十二条但書について指摘している ${ }^{(4)}$ 。

用語法としては、captureは、支配権を握る (taking control) と直ちに法的所有権が英国なら国王に移転 する場合を指し、seizureは、支配権は得るが一時的なもので、捕獲審検所の検定 (condemnation)をまっ 
て初めて所有権が移転する場合を指す ${ }^{(5)}$ 。

フランス語のpriseには二重の意味があり、先ず蕃検 (autorites juridictionnelles)により没收する目的 で敵国或は中立国の商船或は商品の所有権(possession)を交戦国が獲得する海戦にお打る作戦行動 (opération）を意味し、次に当該措置の目的となった船舶或は商品を意味する。即ち夫々捕獲行為と捕獲物を意 味する。captureは船舶に対して捕獲の権利を行使した場合に用いる。saisieは商品或は貨物に対して捕獲 の榷利を行使した場合に用いる。1934年 3 月 8 日のフランス海軍訓令に於ても上の区別がなされていると 言われる ${ }^{(6)}$ 。尤も信夫淳平はcaptureが捕獲、saisieが拿捕に当たり、拿捕が捕獲の予備的行為で、捕獲審 検をまって捕獲物として没収するか解放するか決定されると、H.A.Smithと同じ区別をフランス語の用語 にしている(7)。更に、国連海洋法条約第九十七条第三項及び公海に関する条約第十一条第三項の平時の拿捕 もフランス語ではsaisieである ${ }^{(8)}$ 。

この様に若干の混乱はあるが、戦時或は武力紛争時の捕獲(英語のcaptureやseizure、フランス語の prise) と平時の拿捕 (英語のarrestやフランス語のsaisie) とは区別すべきと思われる。

従って我が船舶法第二十二条第二項の規定が戦時或いは武力紛争時に関する事が明らかである。逆に、 此の規定が我が国の行動を規制するのは、戦時或いは武力紛争時である。小論は、我が船舶法第二十二条 第二項の淵源を探り、その歴史を迎り、立法目的を明らかにして、その現代的意義と欠陷を指摘する事を 試みる。

\section{2. 本論 規定の淵源と歴史}

\section{1 淵源の手掛加り}

我が国の船舶法に酷似している英国商船法第69条の虚偽の国旗の使用の国際法的側面について、 W.Porges とM.Thomas共著の「商船法」は、Oppenheimの「国際法」第七版第二巻p.429.及びW.E.Hallの 「国際法」第八版p.649.を見るべき事を記載している ${ }^{(9)}$ 。Oppenheimの「国際法」は、実際の戦闘中には敵の 国旗の使用は、理論でも実際でも、禁止されている事、但し戦闘開始前なら、敵を誤解させる手段として 敵国旗使用が許されている事を述べている(10)。もっと示唆的なのは、Hallの「国際法」で、軍艦が虚偽の旗 (colours)を用いる事は、一般的に認められた戦術であると言い、「同様の奇計を商船が用いる事の合法性」 が、第一次世界大戦中に、ルシタニア号事件に関連して問題になった事を挙げている ${ }^{(11)}$ 。れうらの記述か ら、我が国の船舶法第二十二条第二項と1894年の英国商船法の第六十九条の規定は、いわゆる戦争の奇計 (ruse of war)の問題である事が窥われる。そして、戦争の奇計には、軍艦が実際の戦闘の前に敵を欺いて、 虚偽の旗を用いる事と並んで、商船が、捕獲から免れる為に旗を用いる事も含まれと主張される事、それ と同時に我が船舶法と英国商船法とは、後者の意味での戦争の奇計の合法性を前提としている事が䚐われ る。

確かに、軍艦による虚偽の旗の使用と商船によるものとは、一対として考えられてきた様である。1912 年の夏のオックスフォード会期で国際法協会が、虚偽の旗の使用を背信的手段として全面的に禁止する草 案を審議したときに、de Reuterskjord氏は、交戦国の商船が捕獲や破壊を免れる為に虚偽の旗を揭げる事 が許されるのに、何故軍艦は許されないのか、と反問している(12)。

R.Bourdoncleも、海戦では、敵国旗や第三国の国旗の偽用(usurpation)が、しばしば奇計として行われ てきた事、軍艦の場合の日的は、敵に警戒心を呼び覚まさないで接近する事にあり、商船の場合は捕獲や 破壊を免孔る為である事を指摘している(13)。両者の関係を最も明確に解明し且つ、存在理由を批判してい るのは、H.A.Smithで、彼は、次の様に述べている;

「海戦で…極めて重要性な奇計は、虚偽の旗の使用である。敵を欺く為の、虚偽の旗を…戦闘に入るときに 真の旗に変えさえすれば、正当化される…攻撃を開始する前に、海軍の標章 (ensign) 揭げさえすれば、 軍艦が…外見を偽り、ときには商船を装う事でさえも許される。商船も又、この様な方法で敵の巡洋艦を 欺く自由がある。‥昔は、この様な規則にも、立派な理由があり、‥海賊や私掠船から逃价事を可能に した。海賊が法に従う筈もなく、私掠船もこの点、大同小異であった。この様な敵の裏をかくのに非難さ れる言われはなかつた ${ }^{(14)}$ 。しかし彼によれば今日ではこの規則は、時代錯䛊であり、固有の役割が終わっ たのに法律として生き恥を唒す一例とされる。 
イギリスが海で支配的立場に立った十八世紀末の戦争でイギリスの監視を失敗させる為に虚偽の旗が使 用されていると非難された。「我々(イギリス)の海での成功と支配にも係わらず、フランスが繁栄している のは、戦争の奇計一中立国の財産でなく敵の財産の保護を目的とする中立国の旗の濫用一に原因がある。 こうして中立国の旗は、敵の保護に役立っている(15)。」

戦時に商船が偽装する事は、厳密な意味では、奇計とは言い難い(16)が、広義の戦争の奇計と理解されて いる。我が国の船舶法第二十二条第二項と1894年の英国商船法の第69条の規定の起源を求めなければなら ないのは、この広義の戦争の奇計についてである。

\section{2 淵源}

ここで海戦における戦闘開始や臨検の規定を探す為に、古い海法を尋ねる事にする。尤も軍の訓令は、

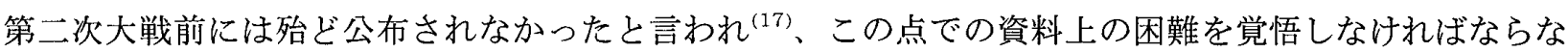
い。

コンソラート・デル・マーレが既に臨検の権利に言及している事をNysが指摘している ${ }^{(18)}$ 。確が、そ の第231条は、巡航している船が、他の船と遭遇し、その船の中に敵の財産があれば、誰もが知っている、 すべき事をするだけだと述べている。但し、ここには掲げるべき旗に関する詳細な規定はない(19)。Nysに よれば十五世紀の条約が臨検の権利に言及しているが、詳細なものになったのは十六世紀になってからと される(20)。

船の旗の揭揚一般について言えば、その歴史は勿論もっと古く、Twissによれば、公海を航行する商船が、 個人と団体とを問わず、所有権を示す旗や目印 (ensign或いはinsigne) を付ける習慣は、極めて古い時代に 遡るとされる。ローマ法は、属州 (provinces)のギルドや団体の船舶所有権を認めていたし(21)、中世時代の 地中海やバルト海の主要な海運都市の制定法から、商船がギルドや団体の旗を掲揚する慣行が十三世紀ま で続いた事が推定される。これに代わって出身都市の旗を船舶が掲げる事を自治都市の法で強制されるに 至り、これを支持する国際慣行が成立し、船舶の出身港の当局が発行する出航許可 (Sea Letter或はCertificatesフランス語ではcongé)を全ての商船が備える事が要求され、これにより、旗に対する船の権原が保証 され、これを欠けば海賊と疑われても仕方がなかった。軍艦が十字軍以来、異なる色の地に金、赤など夫々 の色彩の十字を国の印として付けたのが国旗の始まりとCleiracが言うが、Twiss自身が辿れる最古のもの は、フランスではシャルル五世の1373年12月 7 日の栜令だそうである(22)。

自国の国旗の下で停船命令を下す、少なくとも砲撃は自国の国旗の下で行なわなければならないとの規 則を最初に定めたのはGuérinによればフランスのルイ十六世の勅令の様である( ${ }^{(a)}$ 。古い立法例を適切に説 明していると評されるValinn ${ }^{(23)}$ とよれば、例えば1517年の勅令第19条等が、全てのフランス船がフランスの 旗を掲げなければならないとした。次に戦闘行為の際に他の国旗を揭げる事の禁止は、1650年 2 月 1 日の 国王の布告 (déclaration) 第 4 条に定められ、1662年 8 月13或は17日のコンセーユの判決arrêtで確認され たとされる ${ }^{(24)}$ 。上の布告第 4 条は、「昨年 9 月 7 日の特許状 (lettres patents) 及び同じく昨年 12 月 8 日の 栜令に従い、…我が臣民たる船長が、外国の国王、君主 (prince) 或は共和国から委任状を受ける事を禁止 し、戦闘行為を行う (faire la guerre) 為に我が国旗以外の旗 (bannière)を揭げる事を禁止する；‥」定め ている(25)。この規則は相互主義的に遵守すべきであるが、長い間外国に無視された。それでもルイ十四世 は1674年 2 月23日の勅令により同盟国や中立国の船を明白な理由もなくて捕獲した場合に、もし船主が複 数の旗を持っているならば、公けの敵且つ海賊として訴追する事にした。この勅令の厳しさは、複数の旗 を持っているだけで、捕獲された船を騙し裏切って戦闘に誘い込む為に外国旗を利用したと推定する事に あり、フランスの敵を有利にするものである(26)。

しかし、1681年 8 月の栜令第 5 条は「委任状 (commission)を与えた国…以外の旗の下で戦闘する全ての 船舶…は捕獲物として有效である。もしそれ(船舶)が戦争の為に武装していれば、船長と将校 (officiers) は 海賊として処罰する。と外国旗の下での戦闘にしか言及せず、上の推定を省いている。又、この栜令以来、 私掠船が自ら適当と判断する国旗を船内に備え、必要に応じて使い分ける事が許される様になった。目的 は、遭遇した船を容易に見分ける為に相手が安心する旗を用いて接近する為でも良いし、自分より強力と 信じられる船から逃机る為でも良い(2T)。

Valinによれば、ルイ十四世の1681年 8 月の海事勅令当時のフランスの海軍は、強力ではなく、海軍提督 が自らの費用で武装した例外的な何隻かの船を除けば、私人が私掠船として武装した船でしか海戦が行わ 
れなかった。その為に戦備は疎かにされ、屈辱的な事が起こり、他方では、過度の掠奪が同盟国やフラン ス国民まで害するに至った。この無秩序を制する為に、戦争参加の為に武装する私人が航海に出る前に提 督から、委任状 (commission) を受け取り、船舶の検查を受ける事を義務付け、これに違反すれば、船を没 収する事にした。これが委任状制度の目的である。そこで、1681年 8 月の海事勅令第 3 編第 9 章第 1 条も、 「何人も、海軍提督の委任状がなければ、船を戦争の為に武装してはならない。」規定している。本条の解 説では、戦争を行う権利は、主権者にしかない。敵対行為を合法に遂行する特別の許可即ち、戦争の委任 状 (commission en guerre)を王の名において与える権限を海軍提督の専権とした。この制度の歴史は古 く、1400年の勅令第 3 条に遡るとされる ${ }^{(28)}$ 。委任状を受け取った者は、私掠行為からの逸脱等に備えて 1,500リーブルを保証金として国に預けなければならない(第 2 条) ${ }^{(29)}$ 。これは、友好国と戦闘をした場合の 賠償にあてたり、捕獲物を捕獲審検に付託しない場合に没収する為である。フランス国民は、外国の王か ら戦争の委任状を受ける事を禁じられ、違反すれば海賊として罰せられる(第 3 条 $)^{(30)}$ 。敵の艦船、海賊船 や如何なる主権国の委任状をも持たずに海を航行する船は有効な捕獲物 (bonne prise)であるから、適法 に捕獲できる(第 4 条) $)^{(31)}$ 。

船長が委任状を受け取った国以外の国の旗を掲げて、戦闘を行った場合に有責 (coupable) とされるの は、その船長が、委任状を与えた主権国に対する侮辱をなした点と、当該主権国の国旗を無視した詐欺 (dol et fausseté)の点に関してである(第 5 条) ${ }^{(32)}$ 。

\section{3 展開}

1681年の勅令第 5 条の規定が、1696年 3 月17日の海事勅令に引き継がれ、外国旗を掲げたまま、空砲に よる停船命令 (le coup de semonce ou d'aasurance) を下す事が禁止され、真の国旗、即ちフランス国旗、 を揭げなければならないとされた。違反すれば、罰として、捕獲したもの(provenu)を奪われる。この捕獲 物が敵船と判明すれば国王に没収され、中立船なら全ての費用、損害額及び利子を船長と船主が被捕獲船 主に支払わなければならない。本栜令発布の理由は、フランスの私掠船が外国旗の下で停船命令を出す慣 行を、フランス国王が、国の名誉と信頼及び1681年の勅令に反すると判断した為であり、他国の君主や国 民がこの戦術に騙される事を防ぐ事にあった ${ }^{(33)}$ 。1696年 3 月17日の勅令を解釈した 1704 年 6 月18日の勅令 では、フランス以外の国旗の下で停船命令を出した後で捕獲した場合、その私掠船の海員 (equipage) は、 捕獲物の分配権を奪われない、と定めていた。この結果、没收は、船主と船長の配分の分についてのみ行 なわれる。この1704年の栜令は1706年 1 月23日のarrêt du Conseilで確認された ${ }^{(34) 。}$

フランスの態度に抵触する事件として1699年 6 月 28 日に六隻から成る英国艦隊がBon岬の沖合にフラン ス船二隻を発見して、船尾に白旗(l'enseigne blanche)を掲げてフランス船をおびき寄せようとした事が ある。フランス船は直ちに英国旗を揚げて罠にはまらない事を示したが、英国船に追い付かれ、多勢に無 勢で健闘空しく翌日降伏した。英国船は攻撃前に英国旗に替えたと言われる ${ }^{(35)}$ 。

1740-48年のオーストリー継承戦や1756-63年の七年戦争中には、フランス人もイギリス人に做って、私 掠船のみならず、軍艦までもが、フランス国王の旗以外の旗の下で停船命令を出す慣行に陷り、敵と同じ 戦法を用いる必要を強弁して、外国旗の下でさえ戦闘しなければ良いと主張した ${ }^{(36)}$ 。ある学者は、1756年 の英国とフランスの戦争ではフランスは復仇としてしか虚偽の国旗の下で停戦命令を下さなかったと言 う。尤も、敵の卑怯で背信的行為によって正当化できるものではない、との批判もある ${ }^{(37)}$ 。

革命11年草月 2 日即ち1803年 5 月22日のarrêté第33条は次の様に規定していた。「私掠武装船の船長は、 それが追跡している目的の船に砲撃する(tirer à boulet)前にフランス国旗を掲げる義務がある。これに違 反すれば捕獲物 (produit de la prise)を船長及び船主より奪い、捕獲された船舶が、敵であれば、共和国 に没収し、船舶が中立と審検されれば、船長と船主は、費用損害及び利子を被捕獲船の所有者 (propriétaires)に支払わなければならない。但し、海員と船主の取り決めによって捕獲物から分配される 予定の分は奪われず、審検によって船主に与えられた場合同様に扱われる。」同第34条は次の様に規定して いる。「複数の旗の下で私掠を行ったと立証された全ての船長は、共犯者及び教唆者と共に、海賊として訴 追され、裁判される(38)。」

1696年の栜令では、国籍を確かめる為に停船命令を出す事さえフランス国旗の下でなければならないと 定めていたのに、革命草月 2 日のarrêté第33条で禁止されているのは、国旗以外の旗の下で実弾を撃つ事 (tirer à boulet)即ち戦闘する事である。後者が出されたのは、1802年 3 月27日のアミアンの和約が破れた 
後で、イギリスを敵として戦争を再開していた。イギリスは、兼てから停船命令も敵国国旗の下で行ら慣 行であったから、ナポレオンのフランス政府は遂に、これに対抗して、フランス私掠船にも、戦闘開始と 同時にしかフランス国旗を掲げるを要求しなくなったのである(39)。こうしてフランス船も戦闘開始まで虚 偽の国旗を合法的奇計として用いる事が出来るに至った。

1825年 4 月 10 日のフランスの法律の第 2 条第 3 項では、「ある国から委任状を受け取りながら、その国と は別の国の国旗の下で敵対行為 (actes d'hostilité)を行った全ての艦船の船長並びに将校は海賊として訴 追され、裁判される」と規定されている。国需尚書の草案説明によれば、この規定は、1681年の勅令第 9 章 第 5 条を踏襲したものである。彼によれば、母国の国旗に代えて外国の国旗を用いることは、戦時に敵か ら逃れる目的ならば、無害の奇計に過ぎない。けれども、目的が、捕えようとする相手船に、当方が彼ら の交戦相手ではないと思い込ませ、敵対行為を隱蔽する事にあるなら、重大な国際法違反且つ戦時法違反 であると言われた。草案審議中、本項による保護を中立国民にまで及ぼす事が行き過ぎではないかとの意 見が出たが、ルイ十四世の1696年 3 月17日の栜令が、中立船を保護する度量 (coeur) 示していた点が指摘 された。この為第 3 項が中立船にも適用される無条件(termes absolus)の表現にされた。同法第 6 条によ れば、第 2 条第 3 項の罪には無期懲役が科せられる ${ }^{(40)}$ 。

何れにせよ、虚偽の旗の下で実弾を撃って戦闘する事は、国際法違反であって、有責の者は海賊とみな され海賊として処罰される。ところで1825年 4 月10日の法律第 2 条と第 6 条は私掠船しか念頭に置いてな い。遭遇した船を欺く為に国籍を詐る傾向が最も強いのは、私掠船だからである。軍艦なら、抵抗できな い商船を奇襲しようとか、戦闘を避ける為国籍を隠蔽しようと、将校が苦慮する事態は、想像が難しく、 その対策を考慮した事はない奋)

停船命令について、国際法によれば、軍艦は、自らの国籍を、相手船に知らせる事から始めなければな らない。その為に、空砲を撃つ(tirer un coup de canon à boulet perdu ou à poudre) と同時に、自ら の旗を揭げる。この発砲を、coup de semonce ou d'assurance 誰何及び保証砲(但し、ここでは「停船命 令」と訳す。)と呼ぶ。この信号により、軍艦が、相手船に停船を命令し(semonce) 同時に、軍艦の国籍を保 証(assure)するからである(42)。

この間の捕獲審検事件にHaabet号対Heureux号の事件がある。フランスの私掠船Heureux号が、1799年 2 月13日、カルカッタに向かっているHaabet号と遭遇し、事前の停船命令抜きで、砲撃した。こ秃に対し てHaabet号は、デンマーク国旗を掲げたが、間もなく帆を降ろさざるを得なくなった。一審では、Haabet 号を英国船と認定し、革命七年花月 7 日の雷検でも、同船の捕獲を適法として私掠船の船主、船長及び乗 組員の間での捕獲物の分配を審検した。デンマーク人船主が、捕獲上訴審Conseilに上訴し、Haabet号は、 1798年 1 月19日ハンブルグでイギリス人Benjamin Stoutから購入して、コペンハーグンの公証人に売買証 書を寄託したと述べた。更に彼は、私掠船船長が、事前に停船命令を急った事と、ムーア人の旗を揭げて いた事を攻撃した。上訴審では、売買証書が私的な物に過ぎず、売買前の積量測定証書その他の公的証書 が一切無い事を指摘して、船舶の敵性を認定した。但し、同船長が、虚偽の国旗の下で攻撃する事を放置 し、事前に停船警告を発しなかった事を認定して、1681年の勅令第 3 編、第 9 章、第17条の違反に当たる として罰金五千リーブルを科した。更に1696年 3 月 7 日の法に従い、私掠船の捕獲物に対する権利を否定 し、Haabet号をフランス政府が没収するとした。但し、私掠船船長以外の海員に帰属する分は配当され $た^{(43)}$ 。

フランスは、黒人奴隷貿易廃止後の1845年に訓令 (instructions)を発して、揭揚すべきでない国旗を揭揚 しただけでは海賊行為とはならないと1825年 4 月12日の法律を解釈すべきであるとした。但し国旗の真実 性に嫌疑を掛けられた船舶は、海上警察や軍艦による警戒で命じられれば国籍を通知しなければならない とした ${ }^{(44)}$ 。

1907年 2 月 26日のロンドン宣言第57条は「国旗の移転(transfert de pavillon)に関する規定を除き、船舶 が中立性を有するか又は敵性 (le caractére neutre ou enemie) を有するかはこの船舶が掲揚の権利を有す る国旗 (le pavillon)によって定める。船舶の敵性等を確定する為には、勿論、国旗の他にも、例えば、中 立国旗に移転しているか否か、所有権の敵性、或は船舶管理人の敵性等を検討すべきである。しかし最初 に考慮されるのが国旗であるとした ${ }^{(45)}$ 。 


\section{3. 二大戦における国旗偽用問題}

\section{1 第一次大戦}

\section{1 .1 虚偽国旗の商船による欺用}

大戦初期に、通商に対する潜水艦の攻撃が始まって、商船保護の任に当たる各国の海軍大臣は、敵を欺 く様々の手段を用いて安全を確保しょうとした ${ }^{(46)}$ 。特に、虚偽の国旗と国籍の虚偽の表示 (marque)につい て例えば、1915年 1 月31日英国海軍大臣は、次の様な訓令を秘密の電報によって商船に伝えた。「潜水艦を 特に警戒し、中立国国旗を揭揚するか、英国沿岸に近い所では、何等の国旗も揭揚しない事を勧告する。 英国或は同盟国の軍艦に遭遇したときには、英国国旗を常に揚げなければならない。社旗を掲揚してはな らず、船名や登録港を示す表示はぼかさなければならない。」漁船には、上の訓令の適用がなく、逆に船名 と表示を明らかにしなければならない事が後に明らかにされた。

フランスは1915年 2 月 2 日英国の訓令をフランス商船に回付した上で「英払海峡、北海及びアイルランド 海にあるフランス商船については、これと同じ注意をすべき、より強い理由 (interet)があると小官は考え る」と付け加えた ${ }^{(47)}$ 。

1915年 3 月 9 日のフランスの大臣訓令 (déctet ministérial)による、ドイツ潜水艦による通商に対する攻 撃における商船の船長と船主に対する訓告instructionは次の様に述べている(48)：

「A．夜間にあっては、フランス船が出来るだけ中立船に似る事が重要であり…」

$\ulcorner$ B. 捕獲を免れる為に商船が虚偽の旗や標章 (marquillage) を用いるのは海戦史において確立された慣習 法をなしている。…

「税関その他の公務員には、船舶の外見を、船長と船主が敵を…欺くのに最善と考えた通り、自由に変える 事を許す訓令を出すものである。」

商船を追跡する軍艦は、真の国旗を掲げる義務がない。例えば、1915年 7 月 1 日のドイツ捕獲令第 6 編 第82条は「追跡中は、戦闘旗を掲げる必要はなく、商船の旗の利用も許される。」定めている。これに対応 して捕獲の犠牲者が同じ事をしても認めるべき事は明らかであろう ${ }^{(49)}$ 。

これら交戦国の態度に対して中立国オランダの1915年 2 月15日の対英覚書は、「当該国家の同意無しで、 その国旗を利用する事は、‥濫用である。‥それ(国旗の欺用)は、真の国旗を揭げる中立船に対する疑念 を引き起こす。それは、中立船が敵船であると誤解される恐れをもたらし、この䛊解に基づく危険に中立 船が唒される。…英国商船が(捕獲を免れる) 目的ならオランダ国旗を掲げる権利を有するといら、その根 拠として、(英国商船法の) 規定を援用する事を(オランダ) 王国政府は、認める事ができない。オランダ法 もオランダ国旗の監用を禁止しているが、捕獲を免れる目的で国旗を用いることを有恕する「英国商船法」 の例外規定を置いていない。この問題に関する国際的規定がない以上、各国旗の使用条件を定める権限は、 当該各国家だけにある。と指摘し抗議している。1915年 3 月13日のオランダの新しい覚書は、「オランダの 港の中で、オランダ国旗を掲げ、オランダの国際識別標識を用い、或は、船体の一部にオランダ国籍の外 見を与える性質の特別の標識を描いた、全ての外国商船に対して、オランダ領海から出る事と通過する事 を禁止する」対抗手段を取った ${ }^{(50)}$ 。

ドイツの1915年 2 月10日の対米覚書では、中立国の合法な航海を保護する措置を米国と共に執りたいが、 英国の商船による中立国旗の濫用と、英国の武装商船がドイツ潜水艦に抵抗している事の二つが、ドイッ の努力を困難にしていると述べている(51)。米国はドイツ亡「独・英両国は、戦争の奇計として中立国旗を用 いない様に其々の商船に要求する事に合意する。協定を結ぼうとしたが、失敗した。

ドイツは、商船による虚偽国旗使用を背信行為と非難したが、実はドイツ自身、連合国より前にこれを 勧めていた。1914年 8 月18日以来、駐カナリア諸島フランス領事が受けた報告では、ドイツ船が煙突に描 いた国旗を変えたり、国旗掲揚の要求に頻繁に英国旗を掲げるとのことである(52)。

\section{1 .2 ルシタニア号事件}

1915年 5 月 1 日にニューヨークを出港したルシタニア号は、乗客千二百五十七名、乗組員七百九名を乗 せてリブァプールに向かっていたが、5月 7 日にアイルランド沖でドイツ潜水艦の魚雷攻撃を受けて十八 分で沈没し、千百九十八名を失った ${ }^{(53)}$ 。この内、米国人犠牲者は、百十四名の多数に上った。こ机は、英 国で民衆の憤激を巻起こした ${ }^{(54)}$ 。 
この事件で、英国はドイツが海戦法規、特に臨検関連法規を守らず無警告撃沈に走っている事を非難し たが、中立国は、英国などによる中立国旗の一般的使用を嫌悪し、特にアメリカ合衆国は、中立船が交戦 国船と誤解されて攻撃される危険を強調した上で、中立国旗の一般的偽用を慎む様要請した ${ }^{(55)}$ 。英国は、 米国船も南北戦争中、この奇計を用いた事を指摘し、英国だけを一方的に批判するのは公平に反すると、 抗議した。但し1915年10月20日の、自衛の為に武装した商船に虚偽の国旗を用いるべきといら英国海軍大 臣の秘密の訓令は、撤回し、偽装や旗の偽用を禁止した ${ }^{(56)}$ 。

3.1 .3 第一次世界大戦中軍艦による虚偽国旗の使用例

1915年 2 月17日に、フランス人船員によれば、U-16がノルウェー船Rovska号を臨検するに際して、英 国旗を揭げ、同船から離れていくとき初めてドイツ国旗を掲げたと言われる。1916年 4 月19日には、英国 汽船「シドニー号」が英仏海峡で、フランス船を装った船に攻撃された。アメリカ合衆国の国旗を表示した 板を側面に打ち付けた、おとり船Baralong号が、合衆国国旗の下でU-17を撃沈したと、ドイツから英国が 非難された。但し、罠船側は、国旗を変えたのに潜水艦側が見過ごしたと言い、逆にアメリカ人船員には ドイツの主張を肯定する者もいる。ドイツ船グライフは、ノルウェー国旗を掲げ、船体にも描き、船名を レナ号と称して、英国の罠にはまったとき、大砲の遮蔽物は除いたが、船体に描いた国旗は完全には遮蔽 できなかった。従って戦闘は、ドイツとノルウェー双方の国旗の下で行われた。グライフは、英国補助巡 洋艦を魚雷攻撃した後、撃沈された ${ }^{(57)}$ 。

潜航したまま魚雷攻撃をする潜水艦は、攻撃の前に真の国旗を揭げる規則を守る事はできない。しかし、 潜水艦を除けば、攻撃の前に真の国旗を揭げるという規則、及び虚偽の国旗の下で攻撃する事が背信とし て禁止されている事、は周知徹底していて、ここに背信の例が二三しか挙げられない事が、背信の稀であ る事を証明している(58)。

\section{2 第二次大戦}

\section{2 .1 敵国旗の詐用}

敵国旗の詐用の例は、第二次世界大戦中にも、その例が多く、1940年 4 月 8 日から 6 月 8 日のノルウェ 一作戦で、ドイツのデーニッツ提督は、全軍艦に指令を出し、ノルウェー海軍に遭遇した場合、英国海軍 と自らを偽ること及び、ノルウェ一海軍からの質問に答える為、前以て英国軍艦の艦名を選んでおく事を 命じた。ドイツ海軍の揚陸作戦の開始まで、英国国旗を揭揚し、しかむ、投光器で照明し、臨検されそう になったら、信号で理解不可能を繰り返し、交信を引き延ばし、目的地を尋ねられた場合には、適当な港 を一時的寄港地として答え、更に必要ならば、ドイツ船を追跡しているとまで答える様に指示された。こ れらの指示は、ベルゲンやトロントハイムで忠実に実行され、ノルウェー人を英国船と欺く事に成功した。 虚偽国旗の使用が、ノルウェー作戦では決定的な役割を演じたと言っても過言ではないと言われる。但し、 兵力を揚陸する時点では必ずドイツ国旗を揚げ様である(59)。

他にも、1941年11月19日オランダ商船と偽ったドイツの巡洋艦Kormoranが、オーストラリア巡洋艦シド ニーに遭遇して、戦闘旗la flamme de guerreがマストの頂上の着かないうちに砲撃して致命的損害を与え た。1942年 5 月 1 日にはドイツ補助巡洋艦Michelが英国船を装って英国船Minelaus号を臨検を装って英 国戦闘旗を掲げ、ダッフルコート着用の乗組員を乗込ませて魚雷艇を海に降ろしたが、信号を送る際に綴 りを間違い、英国戦闘旗も不自然だつた為に、魚雷は発射した様だが、奇計には失敗した ${ }^{(60) 。}$

1934年 3 月 8 日のフランスの訓令第91条は「船舶を臨検しようと決めたならば、国旗を揭げた後で、停船 の国際信号を送るか、空砲を撃って、或は、こ扎らの双方を用いて、警告を与えなければならない。」と定 めている。又、1934年10月 1 日のデクレは、フランスの港其の他に入る場合の例外を定め、「緊急の場合に は、空砲による停船命令を省く事ができる。夜間において実弾による停船命令を省く事ができ、許可なく、 禁止水域に侵入した場合には、事前の警告無しに破壊される危険を覚悟しなければならない(61)。」しかし第 二次世界大戦中は、停船命令への言及は少なく、余り問題にならなかった様である。軍艦同士の対決では、 真の国旗を再掲揚するや否や、攻撃したし、通商戦でも停船の手続きが姿を消した様である。大多数の場 合に、ドイツの補助巡洋艦や戦列艦は、敵の商船に遭えば、相手が抵抗して軍艦に被害を与える事を断念 させる為に、真の国旗を揭げると同時に、「マストを吹飛ばすà démâter或はà plein bois」ほどの猛攻撃を した ${ }^{(62)}$ 。

\section{2 .2 虚偽国旗の下での敵対行為実行の禁止}


敵対行為といら文言によって伝統的に理解されてきたのは、封鎖侵犯(forcer)、機雷敷設、揚陸作戦実行 (opérer)、砲撃開始 (ouvrir le feu)である。封鎖の侵犯は必ずしも戦争行為 (acte de guerre)であるとは、 限らない。現代戦では封鎖の有效性が保証されておらず、敵艦に全く気付かれずに封鎖を破る事が出来る からである。虚偽国旗の下での機雷敷設禁止も常に遵守されている訳ではない。1940年 3 月10日ドイツ貨 物船Shiff II 世号は、エストニア船を装って機雷をGoodwin Sandの北に敷設した。ドイツ補助巡洋艦ペン ギンも虚偽国旗の下で、オーストラリア海岸の近くで機雷敷設を行なった様である。機雷敷設を虚偽国旗 の下で禁止されている敵対行為の中に含めるのは、船舶や航海の技術発展を無視した寧ろ時代遅れの考え とも言われる。何故なら、潜水艦なら潜水したままで秘密裡に機雷敷設出来るのに、これを見逃しておい て、水上艦だけに身元を明らかにする義務を課すのは、片手落ちだからである ${ }^{(63)}$ 。

\section{2 .3 フランスにおける商船の旗}

1940年 6 月22日にフランスがドイツと休戦協定を結んだ後に、第一次世界大戦中に中立国が展開した議 論を、フランスも自ら用いた。1942年 2 月 5 日ドイツ汽船Trapani号が戦車やトラックを積んでチュニジア 領土の 2 マイル沖をフランス国旗の下で航行しているのが発見された。フランスのダルラン艦隊提督は、 同盟国が同様のカムフラージュをすると、フランスが䛊解する危険に同盟国船を唒すと言う。又フランス 沿岸部隊が、英国船をカムフラージュした同盟国船から識別しなければならなくなり、英国船に対して執 るべき措置の効果を減殺すると述ベて、フランスの海上交通に与える悪影響を強調した ${ }^{(64)}$ 。

海戦の慣行では、中立国の特殊記章を、敵の記章と同じ次元で一般的に欺用を認めている様であるが、 これには批判がある。両者の次元が全く異なり、中立国民は、戦争の部外者で、戦争当事国民ではないか らである。又海軍国は、傷病者が、一時的には戦争の部外者たらざるを得ないという理由で、傷病者を守 る赤十字の記章の濫用を禁止しようと熱心であった。しかし中立国民は、傷病兵同様、或は其れ以上に、 戦闘に関して第三者である。しかるに、傷病兵のみが何故中立国民より尊重されなければならないのか？ 海軍国が、中立国の記章の濫用の禁止に、それ程熱心ではないのは理解に苦しむという批判である(65)。

\section{4. 結論的考察}

第一次世界大戦中、交戦国商船による中立国旗揭揚につき、特にルシタニア号事件を契機として、アメ リカ合衆国、デンマーク、オランダ等が外交的抗議を行った。散発的な虚偽国旗使用と異なり、広範囲に 亘る一般的使用は、中立船に対する保護を無意味にするからである。その後、多くの国が、外国船による 自国旗の使用を戦時、平時を問わず、禁止するに至っている。また、国際条約も提案されている。

ルシタニア号事件前でも1913年に国際法学会が、この慣行が戦時法規と両立するか検討し、条約案第 15 条「背信的且つ野虽な手段」の表題で、戦争の奇計は合法とするが、背信の手段は禁止した。同第 2 号で「白 旗の濫用、如何なる虚偽の、特に敵の、旗、軍服若しくは標章又は病院施設の表示の使用を」禁止した ${ }^{(66)}$ 。

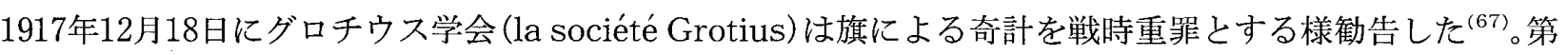
一次世界大戦後の1920年には国際法協会の草案第17条ノ 2 が「交戦国と中立国とを問わず、商船は、如何な る事情の下でも、虚偽の国旗或は旗を揭げてはならない。」定めた ${ }^{(68)}$ 。1939年の「海戦及び空戦における中 立国の権利と義務に関する協約」ハーバード草案の第 20 条は、第 1 項で「交戦国の商船が、中立国の国旗を 表示し、或は、他の方法を以て中立船に偽装する事を交戦国は禁止しなければならない。」とし、第 2 項は 「交戦国の商船が、中立国の国旗を表示し、或は、他の方法を以て中立船に偽装する事を交戦国が承認し、 若しくは、許可した場合には、如何なる中立国も、当該交戦国の全ての商船の、その (中立国) 領域内への 出入りを戦争期間中禁止できるものとする。とし、第 3 項は「交戦国の商船が、(交戦国の) 承認も許可も得 ずに中立国の国旗を表示し、或は、他の方法を以て中立船に偽装した場合には、如何なる中立国も、当該

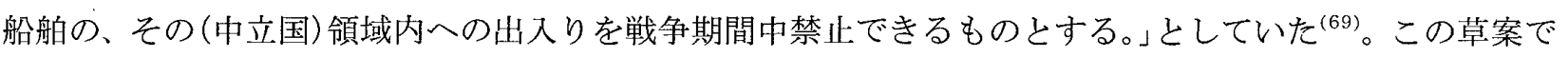
注目すべきは、第 2 項と第 3 項で交戦国の商船が、中立国の国旗を監用すれば、当該中立国にとどまらず 全ての中立国により罰則が科せられる点である。全中立国の共通利益が侵害されたと認識されているので ある(70)。

虚偽国旗使用の慣行の部分的違法化の試みとして「内戦の場合における諸国家の権利と義務に関する、第 六回米州国際会議で採択され、1928年 2 月 20 日ハバナに於いて署名された協約」があり(71)、その第 3 条第 3 
項で、「軍艦と商船とを問わず、行動の盾とする為に外国の国旗を掲げた叛徒の船舶も、当該国旗の国が捕 獲し、裁判する事が出来る。」している。この「裁判」は、船舶と貨物の双方を捕獲審検手続によって捕獲 物として没収する事を含むとde Lupisは解し(72)、更に、このハバナ条約が今日の法を反映していると彼は 解している。

1951年 2 月 8 日ドイツ連邦共和国の国旗法第15条第 2 項(1969年 6 月25日修正 (BGBI I p.645.))では、 「許可 (authorisation) なくドイツ連邦共和国の国旗を海航船の船長が掲げるときは、6ケ月以内の自由刑 (imprisonment) 且つ、又は罰金に処せられる。としている。アメリカ合衆国も、1939年11月 4 日の米国中 立法第14条の a 項は「外国の管轄権の下で操業している或はこれに属する如何なる船舶も、合衆国船である 事を示す標章 (signs) やマーク並びに合衆国旗を用いる事を不法 (unlawfull) とする。」と定め、b 項で「本 条 a 項の規定に違反する如何なる船舶も、合衆国の港或は領水に入る権利を三か月間否定される (denied) ものとする。但し、不可抗力の場合を除く。とする(て3)。オランダも1915年 3 月13日に同国の管轄権内にあ る外国船舶に対して執る措置を声明して、「オランダ国旗を揭げ‥或は、オランダ国籍を有するかの様に偽 装する商船の出航や通過を禁止する (empêcheront)」とした ${ }^{(74)}$ 。

これらの国内法違反は、必ずしも国際法違反とはならないが、今や陸戦と反対の規則を維持するのは時 代遅れである。私掠船に依存せざるを得ない為に海戦の奇計を許した時代には、1898年に既にA.Pilletが指 摘している様に(75)、疑わしい船舶が近づいて危険になる遥か以前から十分の時間的余裕を以て相手を観察 し、対処方法を練る事が出来、仮に追い付かれても、第一撃で撃沈される致命傷を負う事はなかった。と ころが、現代では、武力における認識能力と破壊力の懸隔が甚だしく、視界を遥かに超えて水平線の彼方 まで殺傷兵器が撃ち込まれる。防衛側が視認できる迄待つ事を危険過ぎると考えるであるうし、攻撃側が 船舶の掲げる旗によって攻撃目標とするか否かを決定するとす思えない( ${ }^{(76)}$ 。事情が根本的に変っている現 在では、過去の必要覀による奇計は危険で好ましくないが、軍艦については禁止は困難かも知れない。に も拘らず、戦時或いは武力紛争時におろて商船が外国、特に中立国、の旗を揭げた為、当該外国の船舶の 危険を増大させる恐机の在る場合、掲げる事を禁止する国際立法は可能性があると考えられる。

まして我が船舶法第22条第 2 項は国内法であり、削除する事がハーバード草案の解説によれば、全中立 国の共通の利益に適する。しかも、我が国で規定の正確な意義が忘却され、誤解を受け兼ない実情では、 こ扎を維持すべき理由は無い。削除しないまでも妥協案として法律上の減軽中でも、法定減軽ではなくて、 裁定減軽、即ち、裁量により減軽の出来る形の規定に修正する事も考えられる。この措置により国際武力 紛争時における我が国の外交政策上のフリーハンドを維持できる。

実は、この問題については既に昭和十五年に早稲田大学の一又正男教授により「中村進午博士追悼記念時 局関係国際法外交論集」の491頁で船舶法第22条第 1 項但書(現在の同条第 2 項)が外国に益を与えるのみで ある事を理由に、削除の必要が指摘されている。昭和十六年の信夫淳平著「戦時国際法講義」第三巻381-2頁 でも英国の…我儘の振舞…生をれたる英国の古来の悪慣習による」規則たる事が指摘され、「英国の非を 学んで怪しまざるは解し難い。…帝国船舶法にも第22条に（但し書きとして）‥⿱るるのはその例である。」「軍 艦と商船たるとを問わず一切此れを禁制する事を以て国際法の一原則とすべきである。」主張されている。

拙論に些かの貢献があるとすれば、この規定を成立させた私掠船の歴史的事実の発掘と、一旦法規が成 立すると容易には修正されない保守性を明らかにした点である。

\section{参 考 文 献}

（1）横田喜三郎, 国際法 II, p.150, 昭和 47 年.

(2) W.H.Aggs ed.Chitty's Statutes of Practical Utility, x iii, p.397, 1913.

(3) Draft Convention on Rights and Duties of Neutral States in Naval and Aerial War, Suppl.A.J.I.L., $\mathrm{x} \times \mathrm{x}$ iii, p.357, 1939.

(4) 信夫淳平, 戦時国際法講義, 第三巻, p.381, 昭和十六年.

(5) H.A.Smith, The Law and Custom of the Sea, p.100, 1950.

(6) C.Rousseau, Le Droit des Conflits Armes, pp.276-7, 1983.

（7）信夫淳平，海上国際法，pp.121-122，昭和三十二年.

(8) R.Dupuy et D.Vignes, Traite du Nouveau Droit de la Mer, pp.1225 et 733, 1985. 
(9) W.Porges and M.Thomas, The Merchant Shipping Acts, British Shipping Laws x i, p.52, 1963.

(10) L.Oppenheim, International Law, 7th ed., II, p.429, 1969.

(11) W.E.Hall, Treaties on Interntional Law, 8th ed., p.649, 1924.

(12) Annuaire de l'Institute de Droit International, V, p.525, 1913. 尤も、これは議論が逆転している。 何故なら、後述の様に、軍艦と私掠船が虚偽の旗を掲げる事が許されるから、これに対抗して商船も 許されるからである。

(13) R.Bourdoncle, De l'Influence des Ruses sur l'Evolution du Droit de la Guerre, p.98, 1958.

(14) H.A.Smith, The Law and Custom of the Sea, pp.115-6, 1959.

(15) James Stephan, War in Disguise, 1805, 3rd ed., p.9 as cited by J.Bruneau, La Ruse dans la Guerre sur Mer, p.102, 1938.

(16) R.W.Tucker, The Law of War and Neutrality at Sea, p.142, 1955.

(17) J.Bruneau, supra note 15, p.34.

(18) E.Nys, La guerre maritime, p.73, 1881.

(19) T.Twiss, The Black Book of Admiralty, iii, pp.539-547, 1874.

(20) Nys supra note 18, p.73.

(21) Gaius, 1, 3 ad Edictum Provinciale ; as cited by T.Twiss, The Law of Nations, I , p.321, 1884.

(22) T.Twiss, supra note 21, p.322.都市の旗を強制した法には1270年のハンブルグ法や1299年のリューベ ック法がある。ibid. p.321.

(a) L.Guérin, Histoire Maritime de France, 2ième ed., p.101-1-2.1844.

(23) A.de Pistoye et Ch.Duverdy, Traité des Prises Maritimes dans lequel on a refondu en partie le Traitè de Valin, I, p.231, 1859.

(24) ibid.

(25) Code des prises ou recueil des édits, déclarations, lettres patentes, arrêts, ordonances, règlemens et décisions sur la course et l'administration des prises, depuis 1400 jusqu' à présent, 1ère partie, p.32, 1784.

(26) A.de Pistoye et Ch.Duverdy supra note 23, p.232.

(27) ibid.

(28) René-Josué Valin, Nouveau Commentaire sur l'Ordonnance de la Marine du Moi d'Août 1681, II, pp.213-215, 1766.

(29) ibid., p.221.

(30) ibid., p.235.

(31) ibid., p.237.

(32) ibid., p.239.

(33) Valin supra note 28, p.242 et Code supra note 25, pp.187-188.

(34) Pistoye et Duverdy supra note 23, p.232-233.

(35) Guérin supra note a, pp.102-3.

(36) Pistoye et Duverdy supra note 23, p.233.

(37) F.Perels, Manuel de Droit Maritime International, p.215, 1884.

(38) Pistoye et Duverdy supra note 23, p.233.

(39) ibid., pp.233-234.

(40) ibid., pp.38-41 et 48-49.

(41) ibid., p.234. 原文では第 3 条と言うが、第 6 条は第 2 条にしか触れていないから第 2 条のミスプリと思わ れる。

(42) ibid., p.235.

(43) ibid., pp.239-242.

(44) J.Bruneau, La Ruse dans la Guerre sur Mer, p.102, 1938.

(45) ibid., p.97. 
(46) Bruneau, supra note 15, p.103.

(47) ibid., p.104.

(48) ibid., pp.104-105.

(49) ibid., pp.40 et 114 .

(50) ibid., pp.116-117.

(51) ibid., p.119.

(52) ibid., pp.117-118.

(53) von Glahn, Law among the Nations, p.822, 1992.

(54) Oppenheim, supra note 10, p.308.

(55) G.H.Hackwarth, Digest of International Law, VI, pp.455-6, 1943.

(56) Bruneau, supra note 15, pp.110-112.

(57) ibid., pp.100-101.

(58) ibid., p.101.

(59) R.Bourdoncle, De l'Influence des Ruses sur l'Évolution du Droit de la Guerre, Annales de l'Université de Lyon, Ser.3. Droit Fasc.17, p.99 et 104, 1958.

(60) ibid., p.105.

(61) ibid., p.102.

(62) ibid., p.103.

(63) ibid., pp.103-104.

(64) ibid., p.111.

(65) ibid., p.114.

(66) Draft Convention, supra note 3, p.353.報告者草案では第18条A.I.D.I., x x VI, p.36.1913.

(67) Bruneau, supra note 15, p.30.

(68) Draft Convention, supra note 3, p.353.

(69) ibid.

(70) ibid., p.359.

(71) L.N.T.S.vol.134, p.45, 1932.

(72) I.D.de Lupis, The Law of War, p.260-261, 1987.国旗を濫用された被害国に管轄権を認める事は、最 近のハイジャック防止条約を想起させる。領土を越えた犯罪に対して、違法行為者の国籍にかかわら ず管轄権が認められている点が似ているからである。

(73) D.Fleck, Ruses of War and Prohibition of Perfidy, Revue de Droit Penal Militaire et de Droit de la Guerre, x iii, p.295, 1974; Tucker, supra note 16, p.142, n.43.

(74) Bruneau, supra note 15, p.117.

(75) A.Pillet, Le Libre Usage du Pavillon, R.G.D.I.P., V, pp.445-6, 1898.

(76) W.J.Fenrick, Legal Aspects of Targeting in the Law of Naval Wafare, Canadian Yb.I.L., $x \mathrm{x}$ iv, pp.276-7, 1992.

\section{質 疑 応 答}

橋本 進(東京商船大学)：現在進行中の船舶法改正に報告者の意見がぞの程度反映しているのか？又国旗 として日の丸及び自衛隊旗の地位は如何解积するか？

佐藤好明：最初の御質問につきましては、小生は改正に携わっておりませんので、どの様な状況か存じま せん。個人的には、報告の趣旨の改正又は修正が組込まれ事が望ましいと考えます。第二の御質問につ きましては、報告で取り上げましたのは、national flag, colour, ensigne及びmarkでございまして、船 舶が何れの国籍か又は商船と軍艦の何れであるかを外に示す全ての標章に互る問題であります。但し、 船舶法に関する限りでは国旗のみの問題と御理解を賜りたいと思います。「日の丸」につきましては、先 生御指摘の「商船規則」(明治三年太政官布告)の効力に加えて慣習法上も国旗と解されているのではな いかと思います。 